\title{
Tax Composition and Output Growth: Evidence from Sri Lanka
}

\author{
Mayandy Kesavarajah ${ }^{1}$
}

\begin{abstract}
The role of taxation in determining output growth has been at the centre stage of debate amongst economists, policy makers and researchers over the period. One of the major areas that was more vigorously debated in the field of public finance is whether the changes in tax composition are matters for output growth in the long term. On the empirical front, less conclusive results have been highlighted in the literature. The purpose of this study is to estimate the effects of revenue-neutral tax structure changes on long term economic growth in Sri Lanka within the framework of an endogenous growth model using time series annual data over the period 1980 to 2013. The empirical results of this study indicated while there is an unidirectional causality which is running from income taxes, value added tax and international taxes to output growth, the excise taxes and other taxes are caused by output growth. The study also found negative and statistically significant impacts of income taxes and other taxes on growth. This reflects, apart from income taxes, other taxes which are taxes on other economic activities has hindered the long term growth. Hence, the only robust result appears to be that shifts in tax revenue towards consumption taxes are associated with faster growth.
\end{abstract}

Key Words: Fiscal policy, Tax structure, Growth

JEL Classification: E62, H21, 047

\footnotetext{
1 The author is grateful to Dr. Koshy Mathai of the International Monetary Fund, Prof. Amala De Silva of the University of Colombo and Dr. Hemantha Ekanayake of the Central Bank of Sri Lanka for their valuable comments and suggestions. The author is also thankful to anonymous reviewers. kesavan@cbsl.lk
} 


\section{Introduction}

Do countries with lower tax barriers experience faster economic growth? Few questions have been more vigorously debated in the history of economic literature. It is critical to ask how well the evidence supports the presumption that having lower tax rates would promote growth. Some policy makers argue that increasing taxation is vital to reduce long term debt level and attain macroeconomic stability. Conversely, some policy makers debate that a lower level of taxation promotes both saving and investment and thereby stimulates growth. Along with this, some argue that taxation can be used to attain economic objectives such as fair distribution of income and wealth, efficient resource allocation and economic stabilisation (Musgrave, 1989). However, in the short term, despite the changes in overall level of taxation have an unambiguous impact on aggregate demand, their long term impact on output growth has resulted in much more debate and varied conclusions in the economic literature. In this respect, the role of taxation in determining output growth has emerged as a central question among economists, policy makers and researchers over the periods and emerged as a special policy relevance in the area of public finance. The recent global economic crisis also further intensified on reforming tax structure policies to be in line with "growth promoting" while maintaining fiscal stability in most of the economies. Nevertheless, the outcome of possible impact of taxation on growth would largely depend on the net effect of individual tax components.

Government is an economic agent which collects money through taxation and spends on education, subsidies, infrastructure, government consumption, etc. However, despite the financing of all these government expenditures can be growth retarding, in general, the provision of social and physical infrastructure through government expenditure can improve productivity through a more skilled workforce and efficient allocation of resources. Therefore, issues relating to criteria for the allocation of government expenditure among different sectors and implementing appropriate tax policies are of special policy relevance which are directly related to the country's and development. In the wake of this, understanding the channels through which public finance instruments, such as tax policy, expenditure policy, and overall budgetary policy could affect long term output growth would help policy makers to ascertain how to redirect public expenditure and revenue, and to give more attention to the components of the tax revenue which promote growth. In particular, to which sector the government should allocate its expenditure and on in which activities the government should impose taxes with the objective of stimulating growth while maintaining macroeconomic stability (Afonso and Furceri, 2008).

In practice, many developing countries appear to face severe budgeting pressures with rising demand for expenditures given the limited scope for raising extra government 
revenue. Specifically, the revenue system that are placed in many developing countries themselves generate strong impediments to efficiency, expansion of the economy, growth of tax base, equity and the achievement of development objectives. Hence, tax reform should be at central to public policy and development planning which has been placed by many governments in practice in the recent period.

The objective of this paper is to explore whether there is any revenue-neutral tax structure adjustment that could be associated with faster output growth in the long term in Sri Lanka. In case of Sri Lanka, less conclusive results have been set out in the empirical literature upon the possible impact of taxation on output growth. In this respect, the present study tries to fill the existing gap in the current empirical literature through examining the possible impact of disaggregate tax revenue on the output growth and thereby tries to shed some light on these arguments empirically via analysing comprehensive data ${ }^{2}$ set within the framework of an endogenous growth model. More specifically, the study estimates how changes in the tax structure have affected the long term output growth in Sri Lanka.

The rest of the paper is structured as follows. While section two discusses the theoretical and empirical studies of taxation and growth, section three discusses the data, model, and methodology adopted in this study. Then given the focus of this study, section four is devoted to analyse the trend and composition of tax revenue in Sri Lanka. Section five brings out the empirical evidence on the growth effects of taxation from a time series perspective which would provide more quantitative insights to the policy makers. The final section summarises the major findings and provide policy recommendations.

\section{Literature Review}

\subsection{Theoretical Framework}

Identifying critical factors that determine output growth is important to advocate appropriate policy reforms and to assess their impact on growth and development. Over the decades, a number of growth theories have emerged proposing the determinants of growth within a country and the reasons for differences across countries over the period in the literature (Dornsbush and Fisher, 1990). The most prominent models are the Harrod-Domar growth model, the exogenous growth model of Solow and Swan (1956) and the endogenous growth model. On the theoretical front, while classical economists focused merely on the capacity side (supply side), the early Keynesian economists only studied the problem of demand side. The Harrod-Domar growth theory extended the

${ }^{2}$ Appendix table 3 depicts the result of descriptive statistics of the variables used in this study. 
Keynesian short term analysis and considered both demand as well as capacity effects of investment. In particular, the model explained the growth rate in terms of the level of saving and the productivity of capital and thereby sought to determine the unique rate at which investment and income grow so that full employment level is maintained over a long period of time by considering both demand and supply side of the economy (Gupta, 2008).

A common prediction of the exogenous growth model is that an economy will always converge towards a steady state rate of growth ${ }^{3}$ which depends only on the rate of technological progress and the rate of labor force growth. Furthermore, it predicts that physical or human capital accumulation can affect growth only during "transitional" periods when the economy is out of its steady state (Mankiw et al, 1992). The theory also predicts that, out of steady-state, poorer economies would tend to grow faster than rich ones, given the effect of diminishing returns to capital. In this context, policies including fiscal policies cannot permanently affect economic growth, since they cannot change the rate of savings. However, the limitations of the exogenous growth model have been gradually relaxed in the literature with the development of endogenous growth model by Romer, (1986 and 1990) and Lucas (1990) which captured the impact of human capital accumulation and research and development expenditures on growth.

\section{The Endogenous Growth Theory}

The endogenous growth model developed by Romer and Lucas (1990) will be the main material discussed in this section. The endogenous growth model goes deeper into the question on the ultimate sources of growth and provides a superior justification of growth over time. The emergence of this new growth theory addresses some of the shortcomings of the neoclassical growth theories. Notably, in addition to labour, capital and technology it identified the importance of fiscal policy instruments as an important source in determining output growth. Further, the theory explained the determinants of economic growth by excluding two main assumptions that were incorporated in the neoclassical growth model. The first assumption is that technological change is exogenous, and that it determines the growth rate beyond its steady state. The second assumption is that the same technological opportunities are available to all countries. The theory further explains that the long run economic growth is determined by factors that are internal to the economic system, mainly those factors which create opportunities and inducement to generate new technological knowledge.

\footnotetext{
${ }^{3}$ Robert Solow and Trevor Swan applied the term steady state a bit differently in their economic growth model and they implied that steady state occurs when investment equals depreciation, and the economy reaches equilibrium, which may even occur during a period of growth.
} 
Although the neoclassical growth model emphasised that fiscal policies cannot bring changes in long term growth of output, the endogenous growth model provided a theoretical basis for how fiscal policies can affect the long term growth rate (Barro and Sala-i-Martin, 1992) ${ }^{4}$. Because of market failure, government's fiscal policies can improve factor allocation among different sectors of the economy and thereby privately owned factor productivity and the accumulation of physical as well as human capital also can be increased. The endogenous growth model explained the productivity of growth through various economic incentives. The first strand of this approach emphasises the formation of human capital, including the acquisition of skills and training of workers. A second strand focuses on research and development activities of firms. The third strand focuses on granting of patent rights to ensure temporary monopoly to the inventors of new products (Gupta, 2008). An implication of this theory is that the saving rate can affect the long run growth. The model further emphasises that technological progress takes place through various channels such as innovations, mainly in the form of new products, new processes and new markets which are mainly as a result of on-going economic activities. Similarly, the research and development expenditures undertaken by firms, and implementation of economic policies such as fiscal and trade policies with regard to education, trade, taxes, competition, and intellectual property are some of the other factors throughout which the rate of innovation can be influenced via affecting the costs and benefits of research and development activities. The main implication of this endogenous growth theory is that, government policies, including fiscal policies, can affect the long run growth rate by changing economic agent's motivations to save, invest, and accumulate human capital. While most of the growth models predict that taxes on investment and income have a negative effect on growth, these taxes affect the rate of growth through diverse channels. In particular, they reduce private returns to accumulation. However, all taxes do not affect the rate of growth negatively. In the endogenous growth model, it is argued that taxes and social contributions can hinder growth by distorting the decisions of a representative household that maximises utility over time with respect to income such as savings and investment decisions or decisions concerning the trade-off between leisure and labour.

According to the endogenous growth model, tax policies are used not only to intervene to correct non Pareto optimality states but are also used in pursuing active policies to maintain long run economic growth (Arisoy and Unlukaplan, 2010). Taxes on international trade also have potential negative impacts on growth. In particular, when imposing taxes on capital and intermediate goods, the relative price of both inputs will

${ }^{4}$ Public inputs, natural monopolies or spill-over effects are the main justifications for government intervention in to the economic activities. 
fall, and thus reduces the steady state marginal rate of return on these inputs. These theoretical explanations suggest that the levels of taxes as well as their structures are crucial for growth. Hence, in order to minimise the negative impacts of the taxation, the distortion from taxes should be kept to a minimum in fiscal adjustment strategies through shifting the burden of taxation from investments and/or international trade to domestic consumption (Eken, et al. 1997).

\subsection{Empirical Evidence}

Over the decades, a number of studies have attempted to explore the variable which could properly capture the best fiscal stance of an economy. Out of the three standard fiscal policy variables: government spending, taxation and deficits, the literature does not indicate any one of these as the most representative. While many researchers have made use of tax rates as a proxy for fiscal policy (Lucas, 1990; Engen and Skiner, 1996) others such as Martin and Fardmanesh (1990) and Easterly and Rebelo (1993) have used fiscal deficits to represent fiscal policy in their estimation procedures. Yet others (Barro (1990), Aschauer (1985), Easterly and Rebelo (1993) have used expenditure to account for fiscal policy. However, this section reviews some empirical literature which examined the possible impact of taxation on output growth.

Easterly and Rebelo (1993) examined the relationship among fiscal policy variables, growth rate and development using cross-sectional data over the period 1970 to 1988 in 160 countries and by employing Barro's (1991) cross section regression model. They argued that there is a strong relationship between the development level and the fiscal structure. In particular, they showed that while fiscal policy is only influenced by the scale of the economy, the investment in transport and communication is strongly and positively correlated with the growth rate. However, the overall findings showed that it is difficult to isolate the affects of taxation on growth empirically.

Dowrick (1992) also estimated how taxation could affect the economic growth during the period 1960 to 1985 for selected Organization for Economic Co-operation and Development (OECD) countries and argued that while personal income taxation had significant negative impacts on economic growth, corporate taxes did not. Evans (1997) also examined the impacts of taxation on growth employing panel data for 11 OECD countries. The study found that adjustments of tax rates cannot be associated with permanent changes of real GDP growth, unless permanent changes in taxes are cancelled out by permanent changes in other policy variables. However, the author's findings emerged while excluding the expenditure side of the budget from his analysis. Mendoza et al (1997) showed using panel data for 18 OECD countries for the period of 1966 to 1990 that while tax composition has significant impacts on private investment 
it had no significant effect on economic growth. Folster and Henrekson (2001) noted that average tax rates and the ratio of government expenditure have strong negative effects on economic growth rates using panel data from Organization for Economic Cooperation and Development (OECD) countries during the period 1970 to 1995. The study further showed that countries that have higher average income tax rates experienced lower output rates whereas countries with lower average income tax rates recorded higher output levels.

Lee and Gordon (2005) showed using both cross sectional and panel data regression in 70 countries over the period 1970 to 1997 , that corporate tax rates have significant negative impacts on economic growth rate and therefore concluded that a reduction in corporate tax rate of 10 percent would enhance the annual growth rate nearly by one to two percent. Easterly and Rebelo (1993) used cross country data in developing countries and found that differential taxes and tariffs significantly affected the prices of capital goods and therefore, the variance in the relative prices of capital goods have strong negative impacts on growth rate and slows down the economic growth. Engen and Skinner (1992) developed a generalized model of fiscal policy and economic growth to identify the impacts of fiscal variables on growth rate using data from 107 countries over the period 1970 to 1985 and found a significant and negative impact of government fiscal activity on economic growth rate in both short and long run. Further, the authors argue a 10 percent increase in tax reduces output growth by 3.2 percent annually.

Kneller, Bleaney and Gemmell (1999) showed that an increase in productive expenditure has positive impacts on growth when that expenditure is financed by non-distortionary taxation. However, he noted that an increase in distortionary taxation reduces growth rates significantly. Eken et al (1997) examined the impacts of fiscal policy on economic growth in the Middle East and North African regions during 1980 to 1995 and concluded that reductions in budget deficit; improvements in budgetary structure and effectiveness of government interventions are playing a key role in macroeconomic stability and promoting growth. In a study of the impacts of tax reform on economic growth, Engen and Skinner (1996) showed the negative impacts of tax rate on economic growth. Specifically, they considered the impacts of a 5 percent reduction in marginal tax rate on long run economic growth. The study found that there are 0.2 to 0.3 percent differences in growth rate due to major tax reform. The study also concluded that despite the fact that impacts of tax reform on economic growth may be small, yet such small effects can have large impacts on living standards.

Myles (2009) analyzed the effects of the overall tax burden on growth using cross-country growth regressions. The empirical evidence showed that the net balance of the positive and negative effects of taxation on economic growth differs both across 
countries and over time. Ocras (1999) examined the effects of selected fiscal policy variables such as government consumption expenditure, investment expenditure, deficits and tax receipts, on economic growth over the period 1990 to 2004 using quarterly data from South Africa. The study concluded that although investment expenditure had a positive impact on growth, the size of the impact was less than the impact of consumption expenditure. Further, the study revealed the positive effects of tax receipts on growth. However, it was found that the size of the budget deficit does not have a significant impact on growth.

Jayawickrama (2008) estimated the resilience parameters of tax functions in Sri Lanka over the period 1980 to 2005 . Results showed that the long run responsiveness to income is absolutely low in corporate income taxes. Further, the study indicated that personal income, excise and import taxes are growing in relation to their tax bases. According to the estimated results, the author emphasises that the low buoyancy of corporate income tax and the susceptibility of general goods and service tax to unexpected non-structural shocks are the main causes for the declining revenue-gross domestic product (GDP) ratio in Sri Lanka.

\section{Data, Model and the Methodology}

\subsection{The Data Set ${ }^{5}$}

This study uses time series annual data for the period 1980 to 2013 to coincide with the adoption of economic liberalisation policy in Sri Lanka. All the data were obtained from various issues of the annual report of the Central Bank of Sri Lanka. Further, the study uses data on tax revenues to estimate the impacts of distortionary and non-distortionary taxation on output growth. The theory also indicates that while distortionary taxes have significant impacts on growth, non-distortionary taxation has an insignificant impact on growth. Hence, for the purpose of identifying whether tax structure adjustment associated with the output level, the study considered both aggregate as well as disaggregated data for taxation ${ }^{6}$.

\subsection{Theoretical Model: Barro's Growth Model}

Lucas (1988), Barro (1990) and Rebelo (1991) are some of the studies that provide theoretical arguments to support the importance of policy variables in determining economic growth. Barro (1990) explained the relationship between fiscal policies and growth. This study employs Barro's (1990) growth model in examining the implications of tax policies on economic growth in Sri Lanka. More specifically, the

\footnotetext{
${ }^{5}$ The lists of variables considered in this study are reported in appendix Table 1.

${ }^{6}$ Government tax revenue as a percentage of GDP was considered as a proxy for the taxation.
} 
study attempts to incorporate fiscal as well as non-fiscal variables into the growth model. The assumption in the Barro growth model is that government supported goods and services play an important role from an input to output level. Barro identifies four categories of public finances in order to examine the importance of fiscal policy variables on growth determination; productive expenditures, non-productive expenditures, distortionary taxation, and finally non-distortionary taxation. The detailed explanation on these categories are given below.

Productive and Unproductive Expenditures: Barro (1990) assumed that government expenditure can be treated as productive (growth inducing) when it comes into the production function by contributing directly to output level. If not, it is considered as unproductive expenditure (growth retarding) and does not have any permanent effect on the output level. Corresponding to these explanations, government's consumption expenditure is treated as 'unproductive' because it affect only the consumers' welfare but does not affect the efficiency of private production. Investment expenditure, on the other hand, is treated as 'productive' since it directly affects the output level. At the same time, expenditure on education and health can also be treated as productive because of their effects on human capital accumulation. However, the growth effects of public expenditure on current transfers such as social security remain a questionable issue. However, if these expenditures are merely affecting the welfare; then these expenditure categories can also be treated as 'unproductive' expenditures. On the other hand, transfers may affect savings rates and inequality etc. and could then be either growth enhancing or hindering. Hence, the growth effects of these expenditures, depend on how these expenditures are utilised in the economy.

Distortionary and Non-distortionary Taxes: In Barro's (1990) growth model, 'distortionary' taxes are those which affect investment decisions of investors, in particular, income taxes which can affect the level of output negatively. On the other hand, taxes such as consumption taxes are generally considered as non-distortionary. However, human capital investment can be affected by consumption taxes when labour supply is endogenous (Mendoza et al, 1997). Generally, in practice, nearly all taxes are distortionary to some extent. Hence, the long term effects of taxes can be used to identify whether the distortions which resulted from the implementations of various types of taxes can be expected to be significant or not with respect to the main determinants of the long term economic growth such as investment, education and technology.

According to the Barro model, while distortionary taxation discourages investment in physical and human capital the non-distortionary taxation does not affect the incentives driving such decision making. Furthermore, this model has laid out the channels 
through which tax policy changes affect the output growth (Barro, 1990; King and Rebelo, 1990). The model indicated that the changes in the tax policy not only affect output growth during the short run adjustment process, but it could also have a permanent effect on long term output growth. Meanwhile, the model demonstrates that while productive public expenditures have a positive impact on output level, distortionary taxes on the other hand have a negative impact on output level. According to these arguments, the aggregate production function which depicts how the factor inputs determine economic growth is given as;

$$
y=A k^{1-\alpha} g^{\alpha}
$$

where $k$ represents privately accumulated physical capital and $g$ is government expenditure (public capital) that directly comes into production. Therefore, there is a constant return to total capital inputs which includes public and private capital $(k+g)$. $\mathrm{A}$ is an indicator of technology that captures the total factor productivity (TFP).The government also produces consumption goods for people which is unproductive and is considered not to have any effect on the output level. It is also assumed that the government annually balances its budget by imposing proportional taxes on output at a given rate and by imposing lump-sum taxes. Hence, the government's budget constraint requires balancing expenditures and revenues in every period in the long run which can be specified as:

$$
\mathrm{g}+\mathrm{G}_{0}=\tau . \mathrm{Y}+\mathrm{T}_{0}
$$

Where, $G_{0}$ represents government expenditures that are not directly entered into the production function as inputs, $T_{0}$ represents lump-sum taxation which is non-distortionary with the level of output and $\tau$ is a proportional tax on output which can distort the investment decision of the private sectors and investors.

According to the Barro (1990) model, the growth rate of consumption and output in the steady state can be expressed as:

$$
y=\frac{\dot{c}}{c}=\frac{1}{\theta}\left[A^{*}-\beta\right]
$$

Where,

$$
A^{*}=(1-\tau)(1-\alpha) A k^{-\alpha}(g)^{\alpha}
$$

Equation 3 expresses that growth in output and consumption depends on the gap between the marginal product of capital and the rate of time preference $(\beta)$, and $\frac{1}{\theta}$. $\beta$, and $\theta$ are parameters in the growth model. The higher $\theta$ is the higher returns to capital (MPK) which encourage investment and in turn raises the growth rate of consumption and thereby raises output. The above Barro (1990) model 4 predicts that 
productive government expenditure and distortionary taxation as a share of output positively and negatively affect the long-run growth rate while unproductive expenditure or lump-sum taxation does not have any significant negative effects on output growth in the steady state. Further, the above model indicates that the growth rate is decreasing according to the rate of distortionary taxes and increasing in line with government productive expenditure. However, it is noted that the growth rate is unaffected by both non-distortionary taxes and by the unproductive expenditure. These explanations indicate that fiscal variables from both sides of the budget constraint matter for growth, and therefore failure to include both productive government expenditures and distortionary taxation in the growth model would lead to misspecification.

$$
y=\frac{\dot{c}}{c}=\frac{1}{\theta}\left[(1-\tau)(1-\alpha) A k^{-\alpha}(g)^{\alpha}-\beta\right]
$$

Equation 4 illustrates that government affects the marginal product of capital through two channels. Firstly, increase $g$ which raises the marginal product of capital (MPK). Secondly, taxation which can reduces the private return to capital. Hence, the government needs to concentrate on balancing these two effects.

$$
M P K=(1-\tau)(1-\alpha) A k^{-\alpha} \quad g^{\alpha}
$$

Where, $(1-\tau)$ : Negative effect of taxation

$$
g^{\alpha} \quad \text { : Positive effect of public services }
$$

Table 1 exhibits the growth effects of taxes and expenditure. Generally, the growth effects of public expenditure and taxation are not only dependent on size and type but they also depend on how the deficit is financed. Similarly, growth rate is not only a function of relative productivity of public expenditure but it is also a function of the relative shares of these components in total public expenditures (Gemmell, 2001). Hence, despite all public expenditure being assumed to be productive ${ }^{7}$, an application of distortionary taxes at a high level to finance the deficit may generate a negative impact on the growth rate. Therefore, in order to make use of the Barro model in the empirical analysis (when estimating the growth effects of public expenditure and taxation) it is crucial to incorporate the growth stimulating potential of individual expenditure and revenue components into the long run growth model.

7 Productive expenditure is the component of public expenditure which raises the steady state growth rate of the economy (Deverajan et al. 1996, p.317). 
Table 1: Growth Effects of Taxation and Public Expenditure

\begin{tabular}{|c|c|c|c|}
\hline \multicolumn{2}{|c|}{} & \multicolumn{2}{c|}{ Public Expenditure } \\
\cline { 3 - 4 } \multicolumn{2}{|c|}{ Financed By } & Productive & Unproductive \\
\hline \multirow{3}{*}{ Taxes } & Distortionary & Positive / Negative & Negative \\
\cline { 2 - 4 } & Non-Distortionary & Positive & Zero \\
\hline
\end{tabular}

Source: Gemmell, 2001.

This study will use the above predictions as a basis to interpret the observable pattern of economic growth and fiscal policy instruments. Similarly, the study uses data on economic categorizations of government revenue in order to compute more precisely the effects of distortionary and non-distortionary taxation on the growth rate. This is relatively uncomplicated with respect to taxation, because the classification of direct taxation on property and income, on the one hand, and indirect taxation on imports and production on the other hand, largely reflects the theoretical distortionary/nondistortionary classification (Avila and Strauch, 2008).

$$
y_{t}=\alpha+\sum_{j=1}^{m} \gamma_{t} X_{j t}+\sum_{i=1}^{k} \beta_{t} Y_{i t}+\sum_{j=1}^{n} \eta_{t} Z_{j t}+\varepsilon_{j t} \ldots \ldots \ldots \ldots(6)
$$

The present study considers both fiscal as well as non-fiscal variables in the growth model which are represented in equation 6 . Where, $\mathrm{y}$ is the growth rate of output, $\mathrm{X}$ is a vectors of fiscal variables, and $\mathrm{Y}$ is vectors of non-fiscal variables. $\mathrm{Z}$ is vectors of control variables. $\varepsilon_{j t}$ is the white noise error term. In this model, while investment to GDP ratio is considered as a proxy for the physical capital, education expenditure was taken as a proxy for the human capital input. Endogenous growth theory implies the existence of a balanced budget and therefore;

$$
\sum_{j=1}^{m} \gamma_{t} T R E V_{j t}=\sum_{l=1}^{n} \delta_{t} T E X P_{j t}=0
$$

Furthermore, for productive expenditures, the theory suggests that,

$$
\sum_{l=1}^{n} \delta_{t} T E X P_{j t}>0
$$


And for distortionary taxation,

$$
\sum_{j=1}^{m} \gamma_{t} T R E V_{j t}<0
$$

The coefficient on each variable in the model is interpreted as the effect of a percentage change in the related variable offset by a percentage change in the omitted category on the dependent variable. Moreover, the coefficients of $\gamma, \beta$ and $\eta$ captures the long run effects of fiscal, non-fiscal and control variables on output growth.

\subsection{Methodology}

This study employs econometric techniques of multivariate cointegration and Vector Error Correction Model (VECM) to examine the dynamic relationship among the selected variables. This approach can capture the short run and long run equilibrium dynamics among the variables unlike a simple regression which only reveals the correlation between variables. In practice, as most of the economic times series variables behave as stochastic trends, the first step towards analysis on impacts of taxation on output growth involves the test of stationarity of all the variables. The standard regression models with non-stationary data can lead to the problem of spurious $^{8}$ relationships. Hence, in order to avoid the spurious relationship problem, the difference of the variables has to be included in the cointegration analysis. The test for stationarity ${ }^{9}$ of the individual series in this study has been tested by applying both the Augmented Dickey Fuller (ADF) and Phillips-Perron test.

Furthermore, this study adopts Johanson and Juseliues (1990) method to test for long run cointegration. This method requires that variables entering the cointegration relationship to be integrated of the same order. The two likelihood test statistics known as trace and maximum Eigen value statistics which estimate the number of cointegrating vectors in cointegration procedure will be applied in this study. Moreover, the optimal lag length choice was made by examining the lag structure in an unrestricted VAR using VAR lag order selection criteria. In this respect, the final VAR models will be based on the criteria of Akaike information criteria (AIC) or Schwarz information criteria which minimize the overall sum of squared residuals. If the variables in the underlying regressions are found to be cointegrated, the cointegration approach will be extended to the employment of VECM. The VECM will be estimated

8 Spurious relationship problem can occur when two time series variables in a regression are highly correlated whereas there is no actual relationship between them. High correlation is due to the existence of a time trend in both time series (Granger and Newbold, 1974).

9 A time series is considered to be stationery if its mean and variance are independent of time. If the time series is non-stationary, it is said to have a unit root. Therefore the stationary of a time series is examined by conducting the unit root test. 
to determine the short run dynamics of the regression model. Further, the coefficient of error terms are expected to capture the adjustments of the dependent variable towards long run equilibrium showing the speed of adjustment to the long run solution that enters to influence short run movements in growth, while the coefficients of other independent variables are expected to capture the short run influence on economic growth. The study also uses Ganger causality test to identify any causality among the variables.

\section{Tax Structure and Development in Sri Lanka}

Taxation is a fundamental instrument used by the government to raise revenue for its public expenditure and helps in acquiring sustained growth targets. Similarly, taxes affect economic growth rates in numerous ways: discouraging savings and investment and entrepreneurship decision making by individuals and firms, discouraging work effort and workers' acquisition of skills etc. Tax policy such as direct taxes might distort capital accumulation and thereby reduce the growth rate permanently, while on the other hand indirect taxes which only distort consumption level, would keep capital accumulation and growth unchanged. In particular, taxes imposed on reproducible factors such as physical and human capital, are the most important examples of taxes that reduce the rate of economic growth. In a closed economy, a general consumption tax is a distortionary way of taxing labour, while excise taxes are either Pigouvian taxes, or they distort the allocation by driving wedges between the marginal rates of substitution and the marginal rates of transformation for consumer goods (Christiansen. et al, 1994). In this regard, taxation policy can be used to achieve the fiscal policy goals of fair distribution of income and wealth, efficient resource allocation and economic stabilization etc. (Musgrave, 1989).

Over the decades, with the change in the development strategy, the conventional way of generating revenues in many developing economies has changed. The new approach that many developing economies adopt was minimizing the level of distortions which are generated by tax policies in order to keep the economy more competitive. Besides, these economies also undertake tax reforms to advance their tax system and also to meet the requirements of international competition (Rao, 2002). Meanwhile, it has been widely recognized in both developed and developing economies that countries which have allocated higher expenditure to both education and health sectors were able to enhance their human development indicators. Governments however cannot increase these expenditures unless they are able to generate adequate revenue. Although there are several measures such as money creation, mandating larger required reserves, domestic borrowings and foreign loans which can be generally used to finance government's expenditures, these could have negative macroeconomic consequences 
(Amirthalingam, 2010). Therefore, in order to finance these expenditures, government has to collect revenue from various sources in a way that is equitable, which can improve social welfare and does not distort the structure of price incentives.

The tax reforms undergone in Sri Lanka involve significant changes over the years in keeping with the changing role of different political parties. Sri Lanka embarked on tax reform to revamp its tax systems and to increase its revenue in the face of growing government expenditure and declining tax revenues. However, successive governments of Sri Lanka have provided a number of concessions in the form of tax exemptions and tax holidays to attract more private investment into the economy. At the same time, with the objective of financing increasing public expenditure, the government needs to gather more revenue from various sources such as direct and indirect taxation, surpluses from public enterprises, licensing fees, earnings from the holding of assets and foreign aid (de Silva, 1992). In Sri Lanka, over the decades, despite the economy experienced with high level of output growth and the significant rise in imports, it can be seen that the total government revenue to GDP ratio continuously declined as a result of the abolition of several taxes, the lowering of tax rates and the extension of exemptions (CBSL, 2011).

Figure 1: Government Revenue and Expenditure in Sri Lanka

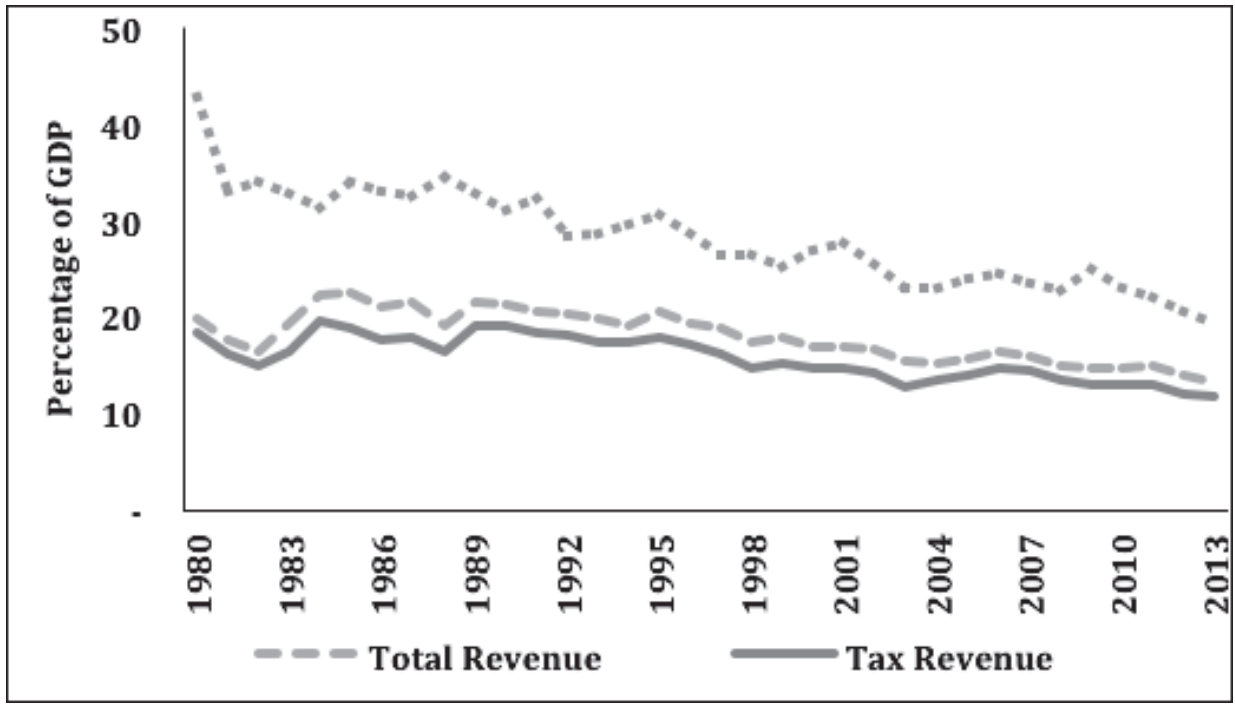

Source: Central Bank Annual Reports (Various Issues)

The total revenue as a percentage of GDP during the 1970's was on average 20 percent, and this ratio increased to 21.1 percent during the 1990 s. However, Since 
the 2000s, it started to show a declining trend and in 2010 was merely about 14.6 percent of GDP (see the figure 1). Similarly, total expenditure shows a declining trend and the gap between total expenditure and revenue remained relatively stable over the period. Against this backdrop, the continued high fiscal deficits ${ }^{10}$ would not only increase concerns about the overall sustainability of the fiscal situation, but would also result in upward pressure on interest rates, and crowd out private investments (World Bank, 2010).

Generally, tax revenue is a major source of total public revenue in many developing economies including Sri Lanka, where nearly 90 per cent of the total revenue is generated through taxation (CBSL, various issues). However, although the tax revenue in absolute terms is continuously increasing as a result of higher revenue from income based taxes, excise duties and import related taxes, it could also be found that tax revenue as a percentage of GDP has continuously declined. During the post economic liberalisation period, the tax revenue was nearly about 82.4 percent of total revenue while the rest is non tax revenue. Since 1990s, however, this trend has changed significantly. In particular, non-tax revenue as a percentage of total revenue increased from 6.6 percent in 1980 to 9.9 percent in 1990 while tax revenue as a percentage of total revenue decreased from 93.4 percent to 90.1 percent in 1990. Similarly, by 2013, while tax revenue was approximately 88.4 per cent of total revenue the rest is non tax revenue. Non-tax revenue increased mainly due to income from profit transfers of public institutions.

Figure 2: Decomposition of Government Revenue in Sri Lanka

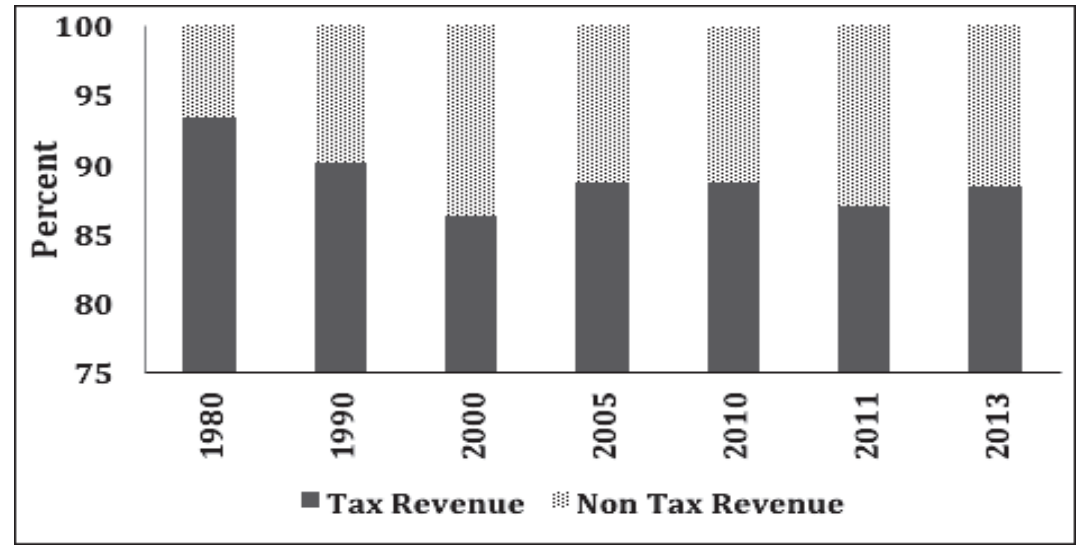

Source: Central Bank Annual Reports (Various Issues)

\footnotetext{
${ }^{10}$ The international evidence suggests that large fiscal deficits are probably the primary cause of macroeconomic instability in most of the economies.
} 
Figure 3: Government Revenue and Output Growth in Sri Lanka

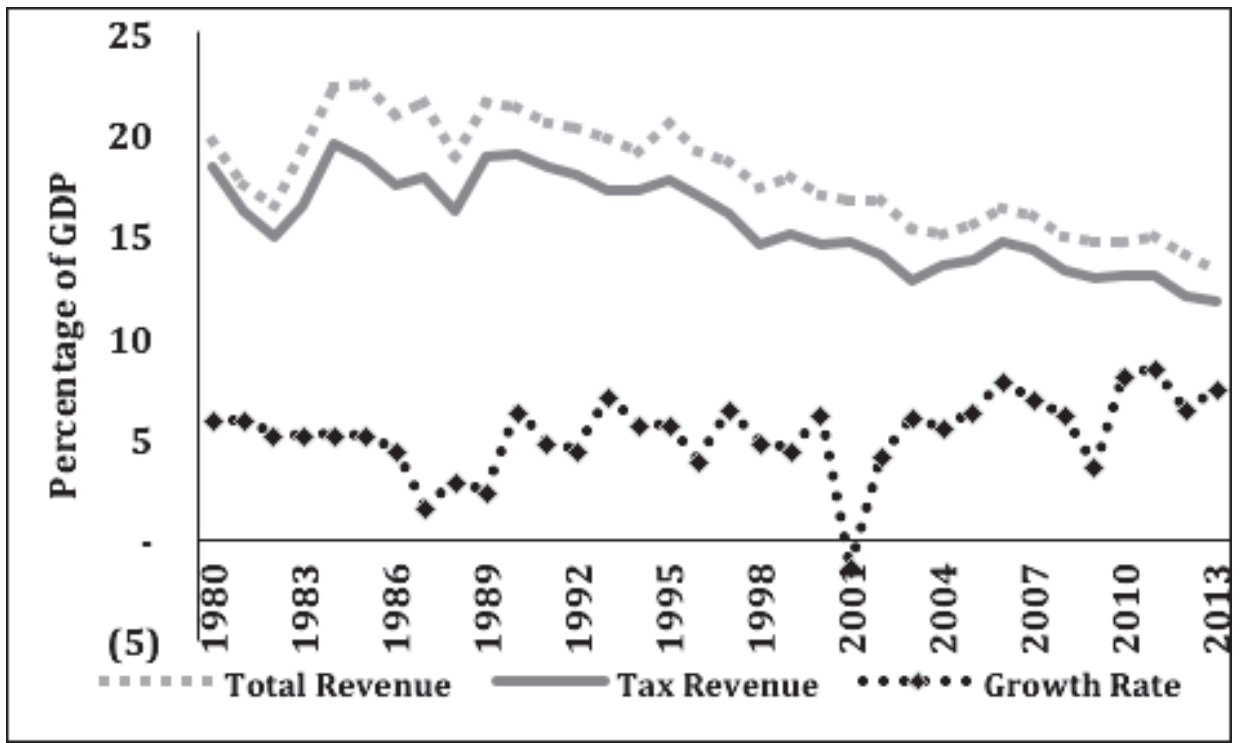

Data Source: Central Bank Annual Reports (Various Issues).

Figure 3 shows the trend of tax revenue as a percentage of GDP in Sri Lanka between 1980 and 2013. The trend shows two distinct phases. Firstly, from 1980 to 1990, there has been a stable increase in the tax revenue to GDP ratio in keeping with the economic conditions and acceleration in the growth rate of the economy. The tax ratio, which was about 15.1 percent in 1977 , increased steadily to 18.7 percent in 1985 . Further, the ratio continued to increase until the early 1990s and reached a peak of 19 percent of GDP in 1990. At the same time, the growth rate also increased from 4.2 percent in 1977 to 6.2 percent in 1990. However, thereafter, despite the economy reaching a reasonable level of growth rate, the tax revenue as percentage of GDP started to decrease gradually. Following further economic liberalisation in the 1990s and the subsequent reforms in the tax system, mainly the reduction in import tariffs has resulted in a decline in the tax to GDP ratio. Moreover, reduction in both quantitative restrictions and tariff levels with the intention of promoting exports has also resulted in a decrease in total revenue as a percentage of GDP. Hence, despite the tax ratio peaking at 19 percent in the early $1990 \mathrm{~s}$, the ratio declined thereafter continuously and recorded 13.7 percent in 2005 and 12.4 percent in 2011 . The main reason for the declining tax revenue-to-GDP ratio was a fall in import duties, as tariffs were lowered. In this context, given that Sri Lanka is currently a lower middle income country; the tax revenue is undoubtedly insufficient from the perspective of the resource necessities of the economy. 
Table 2: Government Revenue in Selected Countries

\begin{tabular}{|l|r|r|r|r|r|r|}
\hline \multicolumn{1}{|c|}{ Countries } & 1990 & \multicolumn{1}{c|}{1995} & \multicolumn{1}{c|}{2000} & \multicolumn{1}{c|}{2005} & 2010 & 2013 \\
\hline Bangladesh & 6.8 & 9.8 & 8.5 & 10.6 & 9.5 & 10.7 \\
\hline Bhutan & 18.8 & 19.1 & 23.2 & 17.0 & 27.4 & - \\
\hline India & 10.7 & 9.9 & 9.8 & 9.7 & 10.6 & 9.4 \\
\hline Maldives & - & 25.8 & 30.0 & 29.8 & 23.4 & 32.6 \\
\hline Nepal & 8.4 & 10.4 & 10.5 & 11.9 & 15.1 & 17.5 \\
\hline Sri Lanka & 21.4 & 20.6 & 16.4 & 15.5 & 14.6 & 13.1 \\
\hline Malaysia & 24.8 & 22.9 & 17.4 & 19.6 & 20.0 & 21.7 \\
\hline Thailand & 17.5 & 18.1 & 14.7 & 17.4 & 16.8 & 18.2 \\
\hline Pakistan & 19.3 & 17.3 & 13.4 & 13.8 & 14.0 & 9.5 \\
\hline Vietnam & 14.7 & 21.9 & 20.1 & 25.7 & 26.7 & 21.9 \\
\hline
\end{tabular}

Source: Key Indicators for Asia and the Pacific 2014

Table 2 presents the trend of government revenue as a percentage of GDP in selected countries from 1990 to 2013. This general picture shows significant differences between countries. From a regional perspective, public revenue-to-GDP ratios in Sri Lanka have been relatively low over the period. It is lower than those of Malaysia, Thailand, Vietnam and Nepal by a large ratio. India and Pakistan's public revenue roughly follows a similar pattern. However, the revenue to GDP ratio in Sri Lanka dropped significantly from 21.4 percent of GDP in 1990 to 15.5 percent of GDP in 2005 and it further decreased gradually to 13.1 percent of GDP in 2013. In Bangladesh, total revenue was only 6.8 percent of GDP in 1990s, and this has merely increased to 10.7 percent in 2013. In India, during 1990s the revenue was 10.7 percent. This decreased to 9.8 percent of GDP in 2000 and gradually decreased to 9.4 percent in 2013. It is also noted that the revenue situation in Pakistan during the 1990s was 19.3 percent, but this has decreased to 13.4 percent in 2010 and again further decreased to 9.5 per cent in 2013. Therefore, the data presented in the above table clearly illustrate that public revenue in Sri Lanka continues to be considerably lower than the selected regional counterparts during the last three decades. Hence, the authorities in Sri Lanka need to prioritise the increasing of public revenues in future to cover increasing expenditure.

In practice, while developing economies are very much dependent on indirect taxes compared to direct taxes, developed economies on the other hand depend a lot on direct 
taxes for revenue generation. Apart from taxes on domestic goods and services, trade taxes plays a more vital role in generating revenues in developing economies than in industrial economies. Domestic taxes on sales are used to influence the pattern of consumption. On the other hand, trade taxes such as import duties are used to influence the pattern of imports. Figure 4 shows how the tax revenue varies over time. Each tax component in figure 5 is expressed as a share of total tax revenue. The figure shows the significant difference between the taxes. Specifically, it indicates that only about one fifth of total taxation is owing to income taxes. Further, the figure shows that there has been a decline in the share of income taxes from 3.1 per cent in 1980 to 2.6 per cent in 1995 and then to about 2.4 per cent in 2011 (See the figure 4).

Figure 4: Trends in Tax Revenue in Sri Lanka: Disaggregated Analysis

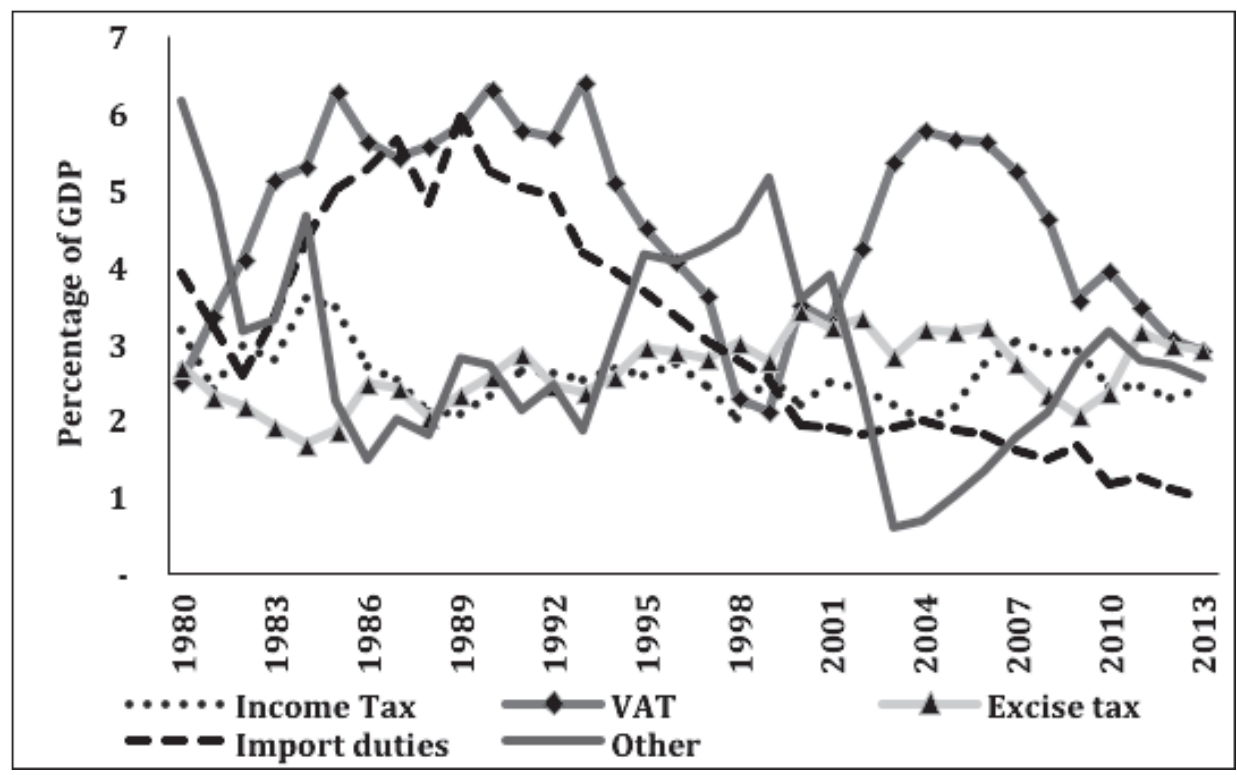

Source: Central Bank Annual Reports (Various Issues) 
Figure 5: Composition of Tax Revenue in Sri Lanka

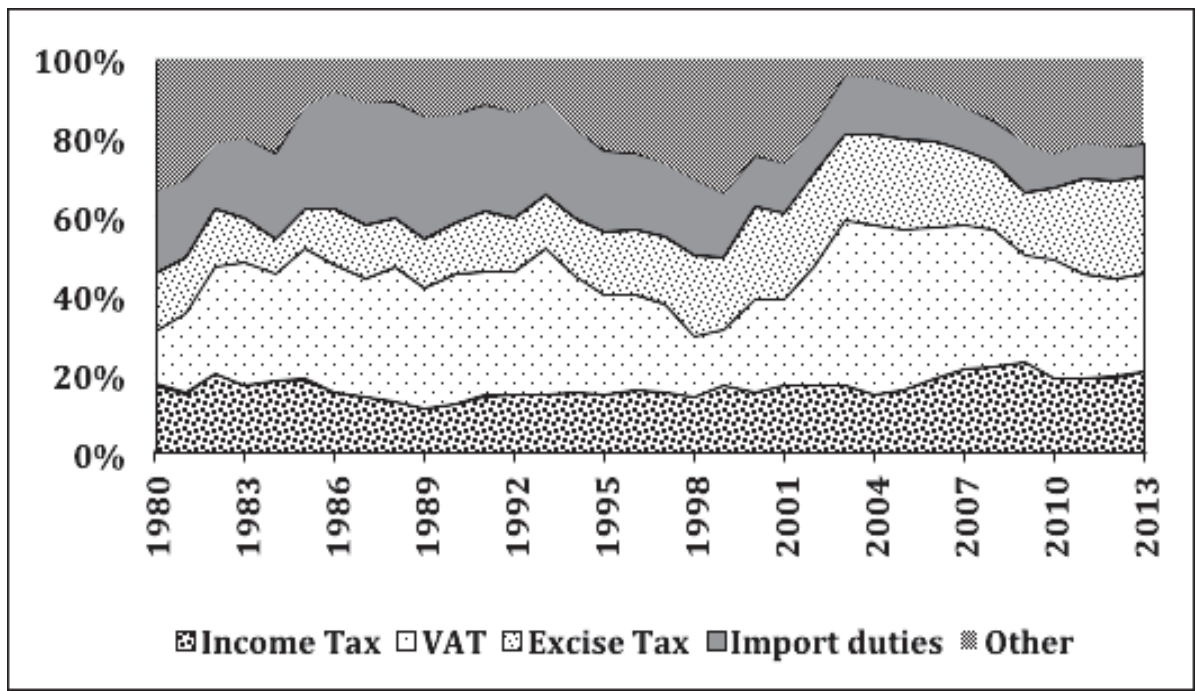

Source: Central Bank Annual Reports (Various Issues)

Following economic liberalisation in 1977 , it can also be noted that the revenue from indirect taxes fell relatively faster than the revenue from other taxes. ${ }^{11}$ With the significant reduction in import duties, the revenue from import duties gradually reduced to 4.4 per cent of GDP in 1980 to 3.6 per cent in 1995 and 1.2 per cent in 2011 . Although the share of revenue from import duties has declined due to the reduction in the tariff barrier, a decline can be seen in the share of revenue from excise taxes, though at a slower rate. However, the growth of tax revenues can be seen in the form of an increase in indirect taxes imposed on goods and services (VAT) ${ }^{12}$ which is considered the primary source of revenue in the economy. Domestic sales taxes have continually increased from 2 percent in 1977 to 6.3 per cent in 1990 and reached a peak of 10.6 per cent in 1995. Subsequently, however, it started to decline continuously and was 5.7 per cent in 2005 and 3.3 per cent in 2011. On the other hand, contributions from excise taxes are also identified as an important source of tax revenue in Sri Lanka, where they

${ }^{11}$ Other taxes refer Ports and Airport Development Levy (PAL), Environment Conservation Levy (ECL), Regional Infrastructure Development Levy (RIDL), and the Social Responsibility Levy (SRL).

${ }^{12}$ Value Added Tax (VAT) was introduced in 2002 and replaced the Goods and Services Tax (GST) which was almost similar to the tax on the consumption of goods and services (GST was introduced in 1988). Prior to GST, Business Turnover Tax was in place (BTT was introduced in 1963 under Finance Act 11 of 1963). 
are equivalent to or even exceed the share of direct income taxes. Further, the other taxes as a percentage of GDP have been continually increasing since 1997. Hence, it can be noted that one of the prominent features of the tax system in Sri Lanka is the low level of revenue from direct taxation in total tax revenue. During last three decades, the average revenue from income taxation including personal, corporate and withholding taxes was only about 2.5 per cent of GDP. The main reasons for this situation are the narrow base of the income tax, the low coverage, the rate structure, low compliance, tax evasion and the number of tax holidays and exemption.

\section{Empirical Estimates of Taxation and Output Growth}

In this paper, the total tax revenue is divided into five major components namely income tax, consumption tax (VAT), excise tax, import duties and other tax revenue. The results of ADF and PP unit root tests are presented in Table 3. Accordingly, the null hypothesis of unit root cannot be rejected at levels for all the variables. Nevertheless, the results indicate that the series are stationery when they are transformed in to first difference form.

Table 3: Test of Unit $\operatorname{Root}^{13}$

\begin{tabular}{|c|c|c|c|c|c|}
\hline \multirow{2}{*}{ Variables } & \multicolumn{2}{|c|}{ ADF } & \multicolumn{2}{c|}{ PP } & $\begin{array}{c}\text { Order of } \\
\text { Integration }\end{array}$ \\
\cline { 2 - 6 } & Level & $\begin{array}{c}\text { First } \\
\text { Difference }\end{array}$ & Level & $\begin{array}{c}\text { First } \\
\text { Difference }\end{array}$ & \\
\hline HC $^{14}$ & -3.0675 & $-7.6132^{*}$ & -3.0421 & $-18.2062^{*}$ & I $(1)$ \\
\hline PC $^{15}$ & -2.3179 & $-4.6282^{*}$ & -4.6963 & $-12.8656^{*}$ & I $(1)$ \\
\hline PPG & -6.0050 & $-9.0067^{*}$ & -2.2324 & $-8.1562^{*}$ & I $(1)$ \\
\hline TREV & -3.7218 & $-5.8029^{*}$ & -2.2514 & $-11.4403^{*}$ & I $(1)$ \\
\hline EG & -2.6405 & $-6.2759^{*}$ & -2.6248 & $-6.2758^{*}$ & I $(1)$ \\
\hline EXT & -2.9140 & $-5.6699^{*}$ & -3.0090 & $-7.8137^{*}$ & I $(1)$ \\
\hline IMD & -1.9195 & $-4.7365^{*}$ & -1.9194 & $-4.7137^{*}$ & I $(1)$ \\
\hline INT & -2.8843 & $-7.1488^{*}$ & -2.5772 & $-7.1191^{*}$ & I $(1)$ \\
\hline M2b & -3.1547 & $-6.3489^{*}$ & -3.1623 & $-8.1213^{*}$ & I $(1)$ \\
\hline OTR & -3.4568 & $-4.6593^{*}$ & -2.5171 & $-4.6842^{*}$ & I $(1)$ \\
\hline TTR & -3.7217 & $-5.8029^{*}$ & -2.2514 & $-11.4403^{*}$ & I $(1)$ \\
\hline VAT & -2.8871 & $-5.7914^{*}$ & -2.8538 & $-9.5657^{*}$ & I $(1)$ \\
\hline
\end{tabular}

Note: $* * *, * *$, and $*$ imply the rejection of the null hypothesis at significance level of $10 \%, 5 \%$ and $1 \%$ respectively.

\footnotetext{
${ }^{13}$ The number of lag selection was based on AIC (see the appendix, Table 2).

${ }^{14}$ Education expenditure as a percentage of GDP was taken as a proxy for the Human Capital.

${ }^{15}$ Investment as a percentage of GDP was taken as a proxy for the Physical capital.
} 
The Johansen and Juselious (1990) co-integration test was adopted to examine the existence of long run association among these variables. The trace and maximum eigenvalue statistics were used to test the null hypothesis of no co-integration. Table 4 reports the results of Johansen's cointegration tests for the null hypothesis of at least one co-integrating vector among economic growth, and fiscal as well as non-fiscal variables. The Johansen cointegration test shows the existence of one cointegrating vector among economic growth, physical capital, human capital, total public expenditure and all sub categories of total government revenue while both tests reject the null hypothesis of no cointegration with one cointegrating vector. Hence, it could be concluded that there is strong evidence to support the existence of a long run association between economic growth and government revenue. This is not an unexpected outcome as Sri Lanka largely depend on tax revenue to meet its expenditure and to achieve sustainable growth.

Table 4: Johansen Test for Cointegration

\begin{tabular}{|c|c|c|c|c|}
\hline \multirow[b]{2}{*}{$\begin{array}{l}\text { Hypothesized } \\
\text { No. of } \mathrm{CE}(\mathrm{s})\end{array}$} & \multicolumn{2}{|c|}{ Test Statistics } & \multicolumn{2}{|c|}{0.05 Critical Values } \\
\hline & $\begin{array}{c}\text { Trace } \\
\text { Statistic }\end{array}$ & $\begin{array}{c}\text { Max- } \\
\text { Eigen } \\
\text { Statistic }\end{array}$ & Trace & Max-Eigen \\
\hline None $* *$ & 105.1877 & 42.3812 & 95.7537 & 40.0775 \\
\hline At most 1 & 62.8065 & 23.5802 & 69.8188 & 33.8768 \\
\hline At most 2 & 39.2262 & 17.4161 & 47.8561 & 27.5843 \\
\hline At most 3 & 21.8102 & 11.1105 & 29.7971 & 21.1316 \\
\hline At most 4 & 10.6997 & 10.3394 & 15.4947 & 14.2646 \\
\hline At most 5 & 0.3603 & 0.3603 & 3.8415 & 3.8415 \\
\hline
\end{tabular}

** denotes rejection of the hypothesis at the 0.05 level

Note: Trend assumption: Linear deterministic trend ${ }^{16}$, Lags interval (in first differences): 1 to 1 ;

However, overall taxation does not have significant impact on output growth (see the appendix table 4). In other words, it implies that not only the aggregate total tax burden but the structure of taxation also matters for growth. In general, some taxes are thought to be more distortionary than others as different taxes have more or less stable tax bases. For instance, high income taxation is often assumed to be more harmful for economic activities than taxation on consumption. This implies that various taxes have different effects on the level of economic activities. Furthermore, as the findings show that there is a long term cointegration among the series, the short run equilibrium of

${ }^{16}$ Cointegration equation includes economic growth, human capital, physical capital, tax revenue, and population growth. 
these series should also be estimated in order to understand the response of these variables in the short run.

The short term coefficients are estimated using Vector Error Correction Model (VECM) and the results are provided in appendix Table 5. The results indicate that changes in tax revenue does not have any influence over short term growth. In particular, the VECM of economic growth in the study appeared statistically insignificant at the 5 per cent level. This indicates that short run deviations of economic growth cannot be explained by the changes in variables that have been included though there appears to be an indication of the presence of other determinants which could have significant influence over the determinant variable but which have not been captured in this study.

Table 5 presents the OLS estimates of long term coefficients. The first difference of series were included for the estimation. The model (1) presents the results of increase in income tax compensated by other tax revenue (tax neutral). Accordingly, the model indicates that an increase in income taxation has a negative and statistically significant impact on growth which supports our initial expectation. Notably, holding other variables of the model constant, a percentage point increase in income taxation is associated with approximately -0.06 percentage point decrease in long term growth. This result is consistent with the findings of Dowric (1992) and Folster and Henrekson (2001), who found a negative and statistically significant impact of income taxation on economic growth. There are several reasons for expecting a negative sign of income taxation. As income taxation includes both corporate and personal income taxation, an increase of these taxation lowers the return on innovations and reduces the amount spent on research and development activities which in turn affects growth negatively. Moreover, corporate taxation can discourages investment both domestically and internationally via reducing foreign direct investment, and thereby would hinder long term economic growth. Conversely, taxation on personal labor income could affect economic growth via influencing investment in human capital and entrepreneurial activities $^{17}$.

17 The impact of the income taxes on entrepreneurial activities depends on how the income from this activity is taxed in individual sectors. 
Table 5: Tax Composition and Output Growth

\begin{tabular}{|c|c|c|c|c|c|}
\hline $\begin{array}{l}\text { Depended Variable } \\
\text { (GDP Growth) }\end{array}$ & $\begin{array}{l}\text { Model } \\
1\end{array}$ & $\begin{array}{l}\text { Model } \\
2\end{array}$ & $\begin{array}{c}\text { Model } \\
3\end{array}$ & $\begin{array}{c}\text { Model } \\
4\end{array}$ & $\begin{array}{l}\text { Model } \\
5\end{array}$ \\
\hline \multicolumn{6}{|l|}{ Baseline Model } \\
\hline \multirow[t]{2}{*}{ Physical Capital } & $0.3297 * * *$ & -0.7039 & $0.3236 * * *$ & $0.2206^{* *}$ & $0.3942 * * *$ \\
\hline & {$[3.0084]$} & {$[-1.009]$} & [3.2513] & {$[2.0676]$} & {$[3.7354]$} \\
\hline \multirow[t]{2}{*}{ Human Capital } & 0.4828 & 0.2511 & 0.3901 & 0.4957 & 0.4726 \\
\hline & [0.3918] & {$[0.5139]$} & [0.3369] & [ 0.4144$]$ & {$[0.4247]$} \\
\hline \multirow[t]{2}{*}{ Population Growth } & $0.6981^{*}$ & 9.9730 & $0.7539 * *$ & 0.8351 & 0.5455 \\
\hline & {$[1.8378]$} & {$[1.1731]$} & [1.9569] & [ 2.2853] & {$[1.5011]$} \\
\hline \multirow[t]{2}{*}{$\mathrm{M} 2 \mathrm{~b}$} & 0.1655 & 0.1019 & 0.0823 & 0.0742 & 0.1522 \\
\hline & [0.8194] & {$[0.8447]$} & {$[0.3812]$} & {$[0.3757]$} & {$[0.8382]$} \\
\hline \multicolumn{6}{|l|}{ Control Variable } \\
\hline \multirow[t]{2}{*}{ Overall Tax Burden } & -0.1279 & -0.1351 & 0.2674 & 0.2448 & -0.1002 \\
\hline & {$[-0.5612]$} & {$[-0.6526]$} & {$[0.0694]$} & [ 0.8667$]$ & {$[-0.63302]$} \\
\hline \multicolumn{6}{|l|}{$\begin{array}{l}\text { Tax Structure } \\
\text { Variables }\end{array}$} \\
\hline \multirow[t]{2}{*}{ Income Taxes } & $-0.0573 * *$ & & & & \\
\hline & {$[-1.9794]$} & & & & \\
\hline \multirow[t]{2}{*}{ VAT } & & $0.3285^{* *}$ & & & \\
\hline & & [2.3209] & & & \\
\hline \multirow[t]{2}{*}{ Excise Taxes } & & & 0.0985 & & \\
\hline & & & {$[0.7781]$} & & \\
\hline \multirow[t]{2}{*}{ Import Duty } & & & & $-0.5576^{*}$ & \\
\hline & & & & {$[-1.8112]$} & \\
\hline \multirow[t]{2}{*}{ Other Taxes } & & & & & $-0.0655^{* *}$ \\
\hline & & & & & [-1.9689] \\
\hline \multirow[t]{2}{*}{$\mathrm{C}$} & -5.2064 & -6.7789 & -8.0933 & 1.3311 & -0.0382 \\
\hline & {$[-0.5676]$} & {$[-0.7910]$} & {$[-0.9773]$} & {$[0.1488]$} & {$[-0.0780]$} \\
\hline R-squared & 0.4242 & 0.4195 & 0.4339 & 0.4838 & 0.5410 \\
\hline DW Stat & 1.9547 & 1.9061 & 1.8808 & 1.9566 & 1.9410 \\
\hline
\end{tabular}

Note: $t$ values are presented in the parenthesis.

$*, * *$, and *** imply the rejection of the null hypothesis at significance level of $10 \%, 5 \%$ and $1 \%$ respectively. 
The study found that the consumption taxes (VAT) appear to have a strong positive and statistically significant impact on growth (model 2). This implies that taxation on goods and services has improved the output growth in Sri Lanka. More precisely, holding other variables of the model constant, a percentage point increase in consumption taxes is associated with approximately 0.33 percentage point increase in long term growth. The positive impact of consumption taxes, notably, VAT could be considered to be more conducive to growth because of their effect on savings and on labor supply. VAT does not impose on savings while income taxes are imposed on savings and on the income from savings (interest). In this regard, consumption taxes such as VAT can encourage savings, leading to increased investment and growth. Also, VAT does not affect people's decisions about whether or not to work, while the income tax system, make people reluctant to work since a higher tax rate will be imposed when people work harder and earn more. Therefore, increase in consumption taxes such as VAT could have a positive impact on growth. However, despite the findings show that consumption taxes or indirect taxes have a positive impact on growth, continues decline in share of indirect taxes on overall tax revenue is still matters for sustainable growth and development. Hence, enhancing the efficiency and productivity of indirect taxation is crucial given the low tax revenue while taking measures to ensure equity in the economy.

In the case of international trade taxes which have been captured in model (4), the coefficient for output growth has a negative sign and is statistically significant at the ten per cent level. It is noted that the share of these taxes declined in response to trade liberalisation. The negative sign could be a result of imposing taxes on capital and intermediate goods which would result in the fall of the relative price of both inputs and thus reduce the steady state marginal rate of return to these inputs. Meanwhile, the results show that excise taxes have a positive impact on growth but are statistically insignificant.

Finally, our results for all other taxes in model (5) show that the coefficients for output growth carry a negative and statistically significant sign leaving us to provide further evidence on the need to explore more on other tax revenue categories to gain a clear understanding of its possible impact on economic activities. Hence, identifying the significant components even within the sub category of this revenue category would help policy makers to formulate effective taxation policies with the view of promoting faster growth and enhancing public revenue in the long term.

Moreover, in the case of other variables which have been included in this study, particularly human capital which has been included in the base line regression model, carry positive signs albeit statistically insignificant. However, despite the coefficient 
sign on this variable indicating a positive impact on output growth, further evidence needs to be captured so as to gain a clear cut understanding of the possible impact of human capital in a more disaggregated manner. Furthermore, the study found that the "physical capital" has a positive effects on growth. This could be driven by the emerging importance of investment in the case of the Sri Lankan economy in achieving its long term growth target. However, it is important to examine whether investment has been affected by the changes in the composition of tax revenue which is beyond the scope of this study. This would give important insights to policy makers in formulating and designing the taxation policies in future.

The results of Granger causality tests are presented in appendix table 6 using a joint F-test approach. The analysis considered the sub-components of tax revenue. The findings indicate the existence of unidirectional causality running from income taxes, VAT and international taxes to growth. It is also found that excise taxation and other taxes are caused by output growth. This finding provides further evidence on how the tax categories are associated with long term output growth.

In summary, the results indicate that investment plays a key role in promoting long term output growth in Sri Lanka. Further, from the taxation perspective, the findings of this study suggest that not only income taxes but other tax categories also matter for output growth. In particular, one of the important long term determinants of Sri Lanka's economic growth has been income taxation, VAT and taxation other than consumption and international trade taxes. Hence, in order to minimise the possible negative impact of taxation, the distortion from taxes should be kept to a minimum level in fiscal adjustment strategies by shifting the burden of taxation from income, and international trade to domestic consumption. Further, it is also recommended to broaden the tax bases which would further enhance the tax revenue in the economy given the low level of public revenue in financing increasing government expenditure.

\section{Summary and Conclusion}

This study explored the differential impact of revenue-neutral tax structure on long term output growth within the framework of an endogenous growth model developed by Barro (1991) in Sri Lanka during the post liberalisation period. In order to assess the response of output growth to increasing public revenue, this study considered five major components of tax revenue namely income taxation, import taxation, VAT (domestic sales tax), excise duties, and other taxation. The results of the unit root test showed that all the variables are non-stationery at levels but all are stationery at first differences. The empirical results of the Johanson cointegration test also found a possible long term relationship between taxation and output growth. The findings show 
that higher level of income taxes, import taxes and other taxes have had negative and significant impact on output growth. Contrary to this, higher level of domestic consumption tax (VAT) shows a significant positive impact on long term output growth while excise taxes do not have any impact. Analysis also indicates unidirectional causality running from income taxes, VAT and international taxes to growth. It was also found that excise taxes and other taxes are caused by output growth. These findings suggest that policy makers need to focus on the sub-categories of public revenue rather than on aggregate revenue ${ }^{18}$.

Therefore, as far as taxation is concern, the findings of this study suggests that the government should increase its taxation on domestic goods and services while reducing income taxes, import taxes and taxes on other sectors aiming at enhancing growth. The results of this study provide a note of concern for policy makers who might believe that the tax system could create distortions in the economy. Thus, based on the evidence, the policy challenge is twofold. First, policy makers could use the results of this study as a rationale to seek tax policies that would mitigate the adverse effects of taxes on growth. Second, as the effects of taxation differ across types of taxes, the government must make further attempts to identify taxes which generate a very low level of revenue but have a very harmful impact on growth. Hence, the results appear to indicate that shifting tax revenue towards consumption taxes would provide a higher level of output growth in the long term. In addition, it is also important to create supportive legal and institutional mechanisms, infrastructure and stable macroeconomic environment which would further facilitate stimulating private sector investment to attain faster growth targets in the long term.

In summary, the study shows that various types of taxation have different degrees of impacts on output growth, implying the existence of significant potential to improve "growth generating efficiency" of taxation. Thus, it cannot simply be suggested that taxation has a negative impact on growth. Rather the findings suggest the existence of greater potential to improve the efficiency of tax revenue in order to promote growth. At the same time, while the study found useful insights on the impact of investment on output growth, it also stresses the need to examine the potential implications arising from different taxation and the nexus between taxation and investment which is beyond the scope this study. However, in order to enhance growth, it is vital to control the possible distortionary effects of taxation on investment.

18 This result is clearly due to the positive and negative impacts of different types of taxation canceling out when the aggregate is considered. 


\section{References:}

Afonso, A. and Furceri, D., (2008). "Government Size, Composition, Volatility and Economic Growth”. Working Paper Series, 849, European Central Bank.

Amirthalingam, K. (2010). "Indirect Taxation in Sri Lanka: The Development Chellenge".Economic Review: Oct/Nov, pp. 11-15.

Arisoy, I. and Unlukaplan, I. (2010). "Tax Composition and Growth in Turkey: An Empirical Analysis".International Research Journal of Finance and Economics, Euro Journals Publishing.

Aschauer, D. A. (1985). "Fiscal Policy and Aggregate Demand".American Economic Review, 75 (1), pp. 117-27.

Barro, R. (1991). 'Economic Growth in a Cross Section of Countries'. The Quarterly Journal of Economics, 106 (2), pp. 407-443.

Barro, R., (1990). "Government Spending in a Simple Model of Endogenous Growth". Journal of Political Economy, 98(1), pp. 103-117.

Barro, R. J., Sala-I-Martin, X. (1992). "Public Finance in Models of Economic Growth", Review of Economic Studies, 159 (4), pp. 645-661.

Barry, W. Poulson and Kaplan, J. G. (2008). "State Income Taxes and Economic Growth". Cato Journal, 28 (1), pp. 53-71.

Central Bank of Sri Lanka, Annual Reports, Various Years.

Christiansen, V. Hagen, K. P. and Sandmo, A. (1994). "The Scope for Taxation and Public Expenditure in an Open Economy". The Scandinavian Journal of Economics, 96 (3), pp. 289-309.

De Silva, (1992), "The Determinants of Private Consumption and the Impacts of Fiscal Policy". A PhD thesis submitted to the University of Sussex, UK.

Dickey, D. A. and Fuller, W. A. (1979). Distribution of the Estimators for Autoregressive Time Series with a Unit Root. Journal of the American Statistical Association, 74, pp. 427-431.

Dornbusch, R. and Fisher, S., (1990), "Macroeconomics", $5^{\text {th }}$ Edition, McGraw - Hill Publishing Company, pp711-745.

Dwivedi, D. N., (2010). "Macroeconomics: Theory and Policy". $3^{\text {rd }}$ Edition, Tata McGraw Hill Education Private Limited New Delhi.

Easterly, W.Rebelo, S. (1993). "Fiscal Policy and Economic Growth: an Empirical Investigation". Journal of Monetary Economics, 32, pp. 417-57.

Eken, S. Helbling, T. and Mazarei, A. (1997). "Fiscal Policy and Growth in the Middle East and North Africa Region”, IMF working paper, WP/97/101. 
Engen, E and Skinner, J. (1992). "Fiscal Policy and Economic Growth", NBER Working Paper, No. 4223. Cambridge.

Engen, E. Skinner, J. (1996). “Taxation and Economic Growth”. National Tax Journal, 49 (4), pp. 617-641.

Evans, P. (1997). "How Fast Do Countries Converge". Review of Economics and Statistics, 79, pp. 219-225.

Folster, S. Henrekson, M. (2001). "Growth Effects of Government Expenditure and Taxation in Rich Countries". European Journal of Political Economy, 45, pp. 1501-1520.

Granger, C. W. J. (1981). "Some Properties of Time Series Data and their use in Econometric Model Specification”. Journal of Econometrics, 16 (1), pp. 121-130.

Gupta, G. S. (2008). "Macroeconomics: Theory and Applications". Visit Tata McGrawHill Companies, 3rd edition: pp. 423-457.

Harris, R and R. Sollis (2003). “Applied Time Series Modelling and Forecasting”. Jhon Wiley and Sons, schchester.

Jayasundera, P. B. (1986). "Fiscal Policy in Sri Lanka since Independence", in Rasaputra et al (eds), Facets of Development in Independent Sri Lanka - Ronnie de Mel Felicitation Volume, Colombo: Ministry of Finance and Planning.

Jayawickrama, A. (2008). "An Examination of the Resiliency of Sri Lanka's Tax System”. South Asia Economic Journal, 9, 351.

Johansen, S. and Juselius, K. (1990). "Maximum Likelihood and Inference on Cointegration with Applications to the Demand for Money". Oxford Bulletin of Economics and Statistics, 52(3), pp.169-210.

Kesavarajah, M. and Ravinthirakumaran N., (2011). "The Impacts of Government Expenditure on Economic Growth in Sri Lanka: An Econometrics Analysis", Conference Proceedings of Eighth International Conference on Business Management, University of Sri Jayewardenepura, Sri Lanka, pp. 163-168.

Keynes, J. M. (1936). “General Theory of Employment, Interest and Money”. Harcourt, Brace and Co, New York, NY, USA.

Key Indicators for Asia and the Pacific 2014

Kneller, R.Bleaney, M. and N. Gemmell. (1999). Fiscal Policy and Growth: Evidence from OECD Countries, Journal of Public Economics, 74, pp. 171-190.

Lakshman, W. D. (2010). "Taxation in the Process of Economic Development: A Discussion Based on Sri Lankan Experience". Economic Review: Oct/Nov, $11-15$. 
Landau, D. L. (1986). "Government and Economic Growth in the Less Developed Countries". Journal of Economic Management, 2 (1).

Lee, Y and Roger, H. Gordon, (2005). "Tax Structure and Economic Growth", Journal of Public Economics, 89, pp. 1027-1043.

Lucas, R. E., (1988). “On the Mechanics of Economic Development".Journal of Monetary Economics, 22, pp. 3-42.

Mankiw, N. G., D. Romer, and Weil, D. N., (1992). "A contribution to the empirics of Economic Growth”. Quarterly journal of Economics, 107 (2), pp. 407-437.

Martin, R. and Fardmanesh, M. (1990). "Fiscal Variables and Growth: A Crosssectional Analysis”. Public Choice, 64 (3), pp. 239-252.

Mendoza, E., G. Milesi-Ferretti and P. Asea, 1997. "On the Effectiveness of Tax Policy in Altering Long-Run Growth: Harberger's Superneutrality Conjecture”. Journal of Public Economics, 66 (1), pp. 99-126.

Musgrave R. A. and Musgrave P. B. (1989). "Public Finance: In Theory and Practice". Mc-Graw-Hill International,NewYork, NY, USA.

Myles, G. D. (2009). "Economic Growth and the Role of Taxation-Theory", OECD Economics Department Working Papers, No. 713, OECD Publishing.

Ormaechea and Yoo, (2012). "Tax Composition and Growth: A Broader Cross Country Perspective”. IMF Working Paper WP/12/257.

Phillips, P. C. B. and Perron, P. (1988). "Testing for a Unit Root in Time Series Regression”. Biometrika, 75(2), pp. 335-346.

Rebelo and Sergio (1991). "Long-Run Policy Analysis and Long-Run Growth," Journal of Political Economy, 99 (June).

Romer, P., (1990). “Endogenous Technological Change”. Journal of Political Economy, 98(5), S71-S102.

Romer, P.M. (1986). "Increasing Returns and Long Run Growth", Journal of Political Economy, 94, pp. 1002-1037.

Solow, R.M. (1956). "A Contribution to the Theory of Economic Growth". The Quarterly Journal of Economics, 70(1), pp. 65-94.

Tanzi, V., and H. Zee. (1997). "Fiscal Policy and Long Run Growth", IMF Staff Papers, 44 (2), pp.179-209. 


\section{Appendix}

Appendix Table 1: Key Description to Variables

\begin{tabular}{cl}
\hline Variables & Description \\
\hline T & Time \\
\hline EG & Annual economic growth rate \\
\hline TREV & Total Revenue as a share of GDP \\
\hline PPG & Population growth \\
\hline S.E & Standard Error \\
\hline PC & Investment as a share of GDP \\
\hline IMT & Import Tax as a share of Total Tax revenue \\
\hline VAT & Value Added Tax as a share of Total Tax revenue \\
\hline INT & Income Tax as a share of Total Tax revenue \\
\hline EXT & Excise Tax as a share of Total Tax revenue \\
\hline OTT & Other tax revenue as a share of Total Tax revenue \\
\hline HC & Education expenditure as a percentage of GDP \\
\hline M2b & M2b as a percentage of GDP \\
\hline INV & Investment as a percentage of GDP \\
\hline TTR & Total Tax revenue as a percentage of GDP \\
\hline
\end{tabular}

Appendix Table 2: Results of VAR Lag Order Selection Criteria

\begin{tabular}{ccccccc}
\hline Lag & LogL & LR & FPE & AIC & SC & HQ \\
\hline 0 & -651.851 & NA & 124695.5 & 40.112 & 40.565 & 40.265 \\
\hline 1 & -405.152 & 328.932 & 22.3625 & 31.221 & 36.209 & 32.899 \\
\hline 2 & -189.463 & $156.864 *$ & $0.1563 *$ & $24.209 *$ & $33.733 *$ & $27.414 *$
\end{tabular}

Note: * indicates lag order selected by the criterion at 5 per cent level of significance. 
Appendix Table 3: Summary Statistics of Key Variables

\begin{tabular}{ccccccc}
\hline & Obs & Mean & Median & Std.Dev. & Min & Max \\
\hline HC & 34 & 2.468 & 2.488 & 0.377 & 1.750 & 3.230 \\
\hline EG & 34 & 5.138 & 5.450 & 1.933 & -1.500 & 8.300 \\
\hline M2b & 34 & 31.483 & 31.945 & 1.873 & 28.138 & 35.264 \\
\hline PPG & 34 & 1.030 & 1.140 & 0.884 & -2.590 & 2.350 \\
\hline INV & 34 & 25.944 & 25.650 & 3.031 & 21.200 & 33.800 \\
\hline TTR & 34 & 15.629 & 15.509 & 2.276 & 11.596 & 19.473 \\
\hline EXT & 34 & 17.286 & 16.672 & 4.627 & 8.521 & 24.923 \\
\hline IMT & 34 & 18.753 & 18.933 & 7.150 & 8.263 & 31.467 \\
\hline INT & 34 & 16.529 & 16.382 & 2.740 & 10.834 & 22.548 \\
\hline OTT & 34 & 18.237 & 18.801 & 8.144 & 4.237 & 34.097 \\
\hline VAT & 34 & 26.935 & 24.701 & 10.719 & 8.236 & 48.041 \\
\hline
\end{tabular}

\section{Appendix Table 4: Long Run Cointegration Equation}

\begin{tabular}{lcc}
\hline & Coefficients & T - Value \\
\hline Intercept & -7.889 & 1.507 \\
\hline Human Capital & $2.296 * *$ & 2.245 \\
\hline M2b & 0.149 & 1.082 \\
\hline Population Growth & $3.597 * * *$ & 7.095 \\
\hline Physical Capital & $0.322 * * *$ & 4.402 \\
\hline Total Revenue & 0.276 & 1.447 \\
\hline
\end{tabular}

Dependent Variable: Economic Growth

Note: $* * *$, and $* * *$ imply the rejection of the null hypothesis at significance level of $10 \%, 5 \%$ and $1 \%$ respectively. 
Tax Composition and Output Growth: Evidence from Sri Lanka

\section{Appendix Table 5: Vector Error Correction (VECM) Estimates}

\begin{tabular}{|c|c|c|c|c|c|c|}
\hline Error Correction & $\mathrm{D}(\mathrm{EG})$ & $\mathrm{D}(\mathrm{EG})$ & $\mathrm{D}(\mathrm{EG})$ & $\mathrm{D}(\mathrm{EG})$ & $\mathrm{D}(\mathrm{EG})$ & $\mathrm{D}(\mathrm{EG})$ \\
\hline \multirow{2}{*}{ Error Term } & $-0.4639 * *$ & 0.3491 & -0.5546 & -0.2619 & 0.1274 & -0.0820 \\
\hline & {$[-1.9803]$} & {$[0.9425]$} & {$[-1.5846]$} & {$[-1.0575]$} & [0.2169] & {$[-1.7955]$} \\
\hline \multirow{2}{*}{$\mathrm{D}(\mathrm{EG}(-1))$} & -0.6084 & -0.7039 & 0.3669 & 0.1719 & -0.3536 & -0.1604 \\
\hline & {$[-1.4162]$} & {$[-1.0092]$} & {$[0.8462]$} & {$[0.4316]$} & {$[-0.7093]$} & {$[-0.4795]$} \\
\hline \multirow{2}{*}{$\mathrm{D}(\mathrm{EG}(-2))$} & -0.2164 & -0.2510 & -0.0600 & 0.1665 & -0.0744 & 0.0573 \\
\hline & {$[-0.7766]$} & {$[-0.5139]$} & {$[-0.2224]$} & {$[0.6016]$} & {$[-0.2449]$} & {$[0.2410]$} \\
\hline \multirow{2}{*}{$\mathrm{D}(\operatorname{EDU}(-1))$} & 0.8254 & 9.9730 & 2.5271 & 1.2194 & 2.0726 & $2.9520 * *$ \\
\hline & {$[0.5388]$} & {$[1.1731]$} & [1.6829] & {$[0.7713]$} & [1.1208] & [2.0065] \\
\hline \multirow{2}{*}{$\mathrm{D}(\operatorname{EDU}(-2))$} & -1.7175 & 1.7975 & -1.3637 & -1.3913 & -0.9539 & -0.2736 \\
\hline & {$[-1.1301]$} & {$[0.4415]$} & {$[-0.9192]$} & {$[-0.9117]$} & {$[-0.5172]$} & {$[-0.1931]$} \\
\hline \multirow{2}{*}{$\mathrm{D}(\operatorname{INV}(-1))$} & -0.2124 & -0.7009 & -0.0008 & -0.4103 & -0.2253 & 0.0225 \\
\hline & {$[-0.6501]$} & {$[-1.4341]$} & {$[-0.0018]$} & {$[-1.2516]$} & {$[-0.4723]$} & {$[0.0634]$} \\
\hline \multirow{2}{*}{$\mathrm{D}(\operatorname{INV}(-2))$} & -0.3284 & -0.0949 & 0.1100 & -0.4357 & -0.2886 & -0.0907 \\
\hline & {$[-1.3208]$} & {$[-0.2759]$} & [ 0.3708] & {$[-1.6318]$} & {$[-1.0069]$} & {$[-0.4194]$} \\
\hline \multirow{2}{*}{$\mathrm{D}(\mathrm{M} 2 \mathrm{~b}(-1))$} & 0.3463 & -0.0918 & -0.1585 & 0.5829 & 0.3742 & -0.0019 \\
\hline & {$[1.0666]$} & {$[-0.1638]$} & {$[-0.3930]$} & {$[1.6855]$} & {$[0.8338]$} & {$[-0.0057]$} \\
\hline \multirow{2}{*}{$\mathrm{D}(\mathrm{M} 2 \mathrm{~b}(-2))$} & -0.0455 & -0.4504 & -0.1215 & -0.1644 & -0.0686 & -0.0458 \\
\hline & {$[-0.1245]$} & {$[-0.8085]$} & {$[-0.3314]$} & {$[-0.4367]$} & {$[-0.1342]$} & {$[-0.1433]$} \\
\hline \multirow{2}{*}{$\mathrm{D}(\mathrm{POP}(-1))$} & 0.9658 & 0.3732 & -0.8858 & 0.8897 & -0.4185 & 0.3093 \\
\hline & {$[0.9431]$} & {$[0.3876]$} & {$[-1.3142]$} & {$[0.6784]$} & {$[-0.4282]$} & {$[0.5437]$} \\
\hline \multirow{2}{*}{$\mathrm{D}(\operatorname{POP}(-2))$} & 0.8835 & 1.4174 & 0.3221 & 0.7532 & 0.17251 & -0.3106 \\
\hline & [1.0449] & [0.9131] & {$[0.4266]$} & {$[0.7512]$} & {$[0.1656]$} & {$[-0.5228]$} \\
\hline \multirow{2}{*}{ D(TTR(-1)) } & $0.8565^{* *}$ & 0.1164 & 0.1539 & 0.2796 & 0.4848 & 0.2087 \\
\hline & {$[2.0795]$} & {$[0.1730]$} & [0.3594] & {$[0.6635]$} & [1.0376] & {$[0.5705]$} \\
\hline \multirow{2}{*}{$\mathrm{D}(\operatorname{TTR}(-2))$} & -0.5653 & -1.2319 & $-1.14582 * *$ & -0.0784 & -0.6205 & -0.4947 \\
\hline & {$[-1.1663]$} & {$[-1.5001]$} & {$[-2.1519]$} & {$[-0.1401]$} & {$[-1.0529]$} & {$[-1.2206]$} \\
\hline \multirow{2}{*}{$\mathrm{D}(\operatorname{IMD}(-1))$} & & -1.0189 & & & & \\
\hline & & {$[-1.1469]$} & & & & \\
\hline \multirow{2}{*}{$\mathrm{D}(\operatorname{IMD}(-2))$} & & -0.1189 & & & & \\
\hline & & {$[-0.2847]$} & & & & \\
\hline \multirow{2}{*}{ D(INCMT(-1)) } & & & 0.1751 & & & \\
\hline & & & {$[0.6965]$} & & & \\
\hline
\end{tabular}




\begin{tabular}{|c|c|c|c|c|c|}
\hline \multirow{2}{*}{$\mathrm{D}(\mathrm{INCMT}(-2))$} & & -0.3616 & & & \\
\hline & & {$[-1.6402]$} & & & \\
\hline \multirow{2}{*}{$\mathrm{D}(\mathrm{OTT}(-1))$} & & & $0.2641^{* *}$ & & \\
\hline & & & [2.1999] & & \\
\hline \multirow{2}{*}{$\mathrm{D}(\mathrm{OTT}(-2))$} & & & -0.1061 & & \\
\hline & & & {$[-1.0227]$} & & \\
\hline \multirow{2}{*}{ D(VAT(-1)) } & & & & -0.0494 & \\
\hline & & & & {$[-0.6184]$} & \\
\hline \multirow{2}{*}{$\mathrm{D}(\operatorname{VAT}(-2))$} & & & & -0.0401 & \\
\hline & & & & {$[-0.4554]$} & \\
\hline \multirow{2}{*}{$\mathrm{D}(\operatorname{EXT}(-1))$} & & & & & $-0.3754 * *$ \\
\hline & & & & & {$[-2.2382]$} \\
\hline \multirow{2}{*}{$\mathrm{D}(\mathrm{EXT}(-2))$} & & & & & 0.2579 \\
\hline & & & & & {$[1.2676]$} \\
\hline \multirow{2}{*}{$\mathrm{C}$} & 0.1272 & -0.1357 & 0.1001 & -0.0382 & $0.1215]$ \\
\hline & {$[0.3061]$} & {$[-0.34518]$} & {$[0.2315]$} & {$[-0.0780]$} & {$[0.3517]$} \\
\hline R-squared & 0.5918 & 0.6687 & 0.6435 & 0.5410 & 0.7542 \\
\hline
\end{tabular}

Note: $* * *$, and $* * *$ imply the rejection of the null hypothesis at significance level of $10 \%, 5 \%$ and $1 \%$ respectively. 


\section{Appendix Table 6: Pair wise Granger Causality Tests}

\begin{tabular}{|c|c|c|c|}
\hline Null Hypothesis & Obs & F- Stat & Prob \\
\hline HC does not Granger Cause EG & \multirow{2}{*}{34} & 2.6814 & 0.0866 \\
\hline EG does not Granger Cause HC & & 0.9719 & 0.3916 \\
\hline TTR does not Granger Cause EG & \multirow{2}{*}{34} & 2.6817 & 0.0866 \\
\hline EG does not Granger Cause TTR & & 0.1758 & 0.8397 \\
\hline EXT does not Granger Cause EG & \multirow{2}{*}{34} & 0.3983 & 0.6753 \\
\hline EG does not Granger Cause EXT & & 3.9327 & 0.0317 \\
\hline OTT does not Granger Cause EG & \multirow{2}{*}{34} & 2.0146 & 0.1529 \\
\hline EG does not Granger Cause OTT & & 3.2410 & 0.0548 \\
\hline INCM does not Granger Cause EG & \multirow{2}{*}{34} & 1.2353 & 0.3067 \\
\hline EG does not Granger Cause INCM & & 4.1961 & 0.0259 \\
\hline IMD does not Granger Cause EG & \multirow{2}{*}{34} & 6.5041 & 0.0049 \\
\hline EG does not Granger Cause IMD & & 0.3175 & 0.7306 \\
\hline VAT does not Granger Cause INV & \multirow{2}{*}{34} & 1.0845 & 0.3523 \\
\hline INV does not Granger Cause VAT & & 2.5836 & 0.0940 \\
\hline OTT does not Granger Cause INV & \multirow{2}{*}{34} & 0.2053 & 0.8156 \\
\hline INV does not Granger Cause OTT & & 2.5568 & 0.0962 \\
\hline VAT does not Granger Cause INV & \multirow{2}{*}{34} & 1.0845 & 0.3523 \\
\hline INV does not Granger Cause VAT & & 2.5836 & 0.0940 \\
\hline INCMT does not Granger Cause INV & \multirow{2}{*}{34} & 1.3175 & 0.3317 \\
\hline INV does not Granger Cause INCMT & & 2.4131 & 0.1215 \\
\hline
\end{tabular}

Note: The number of lag that has been selected in the granger causality test is 2 